\title{
Intermittent Morphine Administration Induces Dependence and is a Chronic Stressor in Rats
}

\author{
Hani Houshyar*, ',2, Francisca Gomez', Sotara Manalo', Aditi Bhargava' and Mary F Dallman' \\ 'Department of Physiology and Neuroscience Program, University of California San Francisco, San Francisco, CA, USA
}

\begin{abstract}
Although constant treatment with morphine (implanted pellets) does not activate the hypothalamic-pituitary-adrenal (HPA) axis, intermittent injections of morphine may constitute a chronic stressor in rats. To test this hypothesis, we compared the effects of morphine in escalating doses ( $10-40 \mathrm{mg} / \mathrm{kg}$, s.c.) or saline injected twice daily for 4 days on energy balance, hormones, HPA responses to novel restraint and central corticotropin-releasing factor (CRF) mRNA $12 \mathrm{~h}$ and 8 days after the last morphine injection in adult male Sprague-Dawley rats. Weight gain stopped at the onset of morphine, weight loss was marked $36 \mathrm{~h}$ postmorphine; thereafter, body weight gain paralleled saline controls. At $12 \mathrm{~h}$, insulin, leptin, and testosterone concentrations were reduced but normalized by 8 days. Restraint and tail nicks caused facilitated ACTH responses at $12 \mathrm{~h}$, under-responsiveness at 8 days. CRF mRNA, measured only at $12 \mathrm{~h}$, was increased in the paraventricular (PVN) and Barrington's nuclei (BAR), decreased in the bed nuclei of the stria terminalis (BNST) and unchanged in the amygdala (CeA) in morphine-treated rats. After stress, CRF mRNA increased in PVN in both groups, increased in BAR and decreased in BNST in saline but not morphine groups, and was unchanged in CeA in both groups. Results from all variables characterize intermittent morphine injections as a chronic stressor. In contrast to constant treatment, injected morphine probably allows some withdrawal during each $12 \mathrm{~h}$ interval, causing repeated stress. Drug addicts treat themselves intermittently, and stress causes relapse after withdrawal. Thus, intermittent morphine, itself, may promote relapse.

Neuropsychopharmacology (2003) 28, 1960-1972, advance online publication, I 3 August 2003; doi: | 0.I038/sj.npp. I 30027 I
\end{abstract}

Keywords: morphine; dependence; withdrawal; stress; energy balance; HPA axis

\section{INTRODUCTION}

Drug addiction comprises compulsive drug craving, drug seeking, and drug use even in the face of negative consequences (Leshner and Koob, 1999). An important component of drug addiction is that it is a chronic relapsing disorder with cycles of reinstatement of drug taking after repeated attempts to abstain. A major factor that contributes to reinstatement after abstinence is stress. In humans, the majority of relapses occur during states of stress (Koob and Le Moal, 2001; Kreek and Koob, 1998). Similarly, in animal models, stressors also reinstate opioid self-administration (Shaham et al, 1997, 1998; Shalev et al, 2001). Furthermore, induction of a 'stress-like' state by intracerebroventricular injection of corticotropin-releasing factor (CRF) reinstates heroin seeking (Shaham et al, 1997),

\footnotetext{
Supported in part by DK28I72.

* Correspondence: Dr H Houshyar, Department of Physiology, University of California San Francisco, San Francisco, CA 941430444, USA, Tel: + I 4I5 476 386I, Fax: + I 4154764929 ,

E-mail: hani@itsa.ucsf.edu

'Supported by F32-DAI4I 43.

Received 10 January 2003; revised 08 April 2003; accepted 28 May 2003

Online publication: 19 June 2003 at http://www.acnp.org/citations/ Npp06 19030300 I5/default.pdf
}

whereas CRF receptor antagonists attenuate stress-induced relapse to drug seeking in heroin-trained rats (Shaham et al, 1997, 1998). CRF appears to mediate stress-induced reinstatement of drug seeking.

CRF integrates many of the endocrine, behavioral, and autonomic responses to stressors and is implicated in many aspects of drug addiction as well (Sarnyai et al, 2001). High concentrations of CRF are located in the medial parvocellular division of the paraventricular nucleus (mpPVN) of the hypothalamus. These neurons release CRF into the pituitary portal system triggering release of ACTH and then adrenal glucocorticoids. The central nucleus of the amygdala (CeA), the bed nuclei of the stria terminalis (BNST), and Barrington's nucleus in the brainstem also contain groups of CRF-synthesizing neurons that interact functionally with the PVN to modulate acute as well as chronic stress responses (Dallman et al, 2002; Imaki et al, 1991; Koob and Heinrichs, 1999; Ma and Aguilera, 1999; Ma et al, 1999; Makino et al, 1999). Altered activity of the hypothalamic and extrahypothalamic CRF network as a consequence of chronic exposure to opioids probably contributes to the vulnerability to relapse.

Although the first injection of morphine stimulates the hypothalamic-pituitary-adrenal (HPA) axis in awake rats (Buckingham, 1982; Milanes et al, 1993), chronic treatment with morphine provided by constant infusions or implanted 
pellets does not activate the HPA axis (Eisenberg, 1985; Laorden et al, 2000; Milanes et al, 1993, 1997; Pechnick, 1993; Sarnyai et al, 2001). During treatment, hypothalamic CRF does not increase (Lightman and Young, 1988; McNally and Akil, 2002; Milanes et al, 1997; Zhou et al, 1996), and circulating ACTH and corticosterone are low (Laorden et al, 2000; Milanes et al, 1997, 1998). Furthermore, morphine dependence induced by pellet implantation attenuates HPA responses to subsequent novel stimuli (Chang et al, 1996; House et al, 2001). In marked contrast to the above, intermittent treatment with escalating doses of morphine results in elevated basal ACTH and corticosterone concentrations (Houshyar et al, 2001b) as well as facilitated pituitary-adrenal responses to novel restraint in rats tested just prior to their expected next injection (Houshyar et al, $2001 \mathrm{a}, \mathrm{b})$. Facilitation after a new stimulus is a characteristic response to chronic stress exposure (Dallman and Bhatnagar, 2001) and suggests that cycles of marked stimulation of the HPA axis may occur in response to repeated cycles of partial withdrawal associated with intermittent drug administration.

Similarly, in humans, opioid addiction appears to be a chronic stressor when partial withdrawal occurs before the next dose. The induction of dependence, withdrawal, and abstinence phases of addiction resemble the effects found during these periods in rats (Kreek et al, 2002). On the street, short-acting opioids, such as heroin, are taken intermittently and those who take them are stress hyperresponsive (Cami et al, 1992). In contrast, addicts maintained on the long-acting opioid methadone during detoxification have low cortisol concentrations and are stress hyporesponsive (Gerra et al, 2001; Mutti et al, 1992; Vescovi et al, 1989). Intermittent treatment with escalating doses of morphine closely parallels the drug use pattern observed in opioid addicts and thus serves as an excellent model for studying perturbations of the HPA axis in response to opioid dependence.

Here, we tested the hypothesis that short-term opioid dependence induced by intermittent morphine injections is a chronic stressor that alters brain CRF and hypothalamic AVP, thus resulting in modified pituitary-adrenal responses to a novel stressor. We delivered morphine in escalating doses at $12 \mathrm{~h}$ intervals for 4 days, and examined HPA activity under basal and stress conditions $12 \mathrm{~h}$ and 8 days after the final morphine injection. As changes in energy balance are sensitive indices of stress in rats (Dallman, 2001), we measured energy balance, metabolic hormone levels, and fat depot weights in response to morphine dependence and withdrawal.

\section{MATERIALS AND METHODS}

\section{Subjects}

Male Sprague-Dawley rats 60 days old (Bantin and Kingman, Gilroy, CA), weighing $250-300 \mathrm{~g}$ at the beginning of experiments, were used for these studies. Rats were housed individually in hanging wire cages with free access to food (Purina Rodent Chow, Diet 5008) and water. They were housed in a room maintained under standard conditions of light (lights on, 0700-1900) and temperature $\left(22 \pm 2^{\circ} \mathrm{C}\right)$. Experiments were initiated shortly after lights on, between
0700 and 0730 . All experimental procedures were approved by the Committee on Animal Research, University of California, San Francisco and performed according to the Guide for the Care and Use of Laboratory Animals of the Institute for Laboratory Animal Reseach, Commission on Life Sciences, National Research Council (Department of Health, Education and Welfare, publication ISBN 0-30905377-3, revised 1996).

\section{Morphine Dependence and Withdrawal}

On the basis of previous studies, morphine dependence was induced by subcutaneous injections of morphine (National Institute of Drug Abuse) twice daily (0700 and 1900) for 4 days with increasing doses $(10,20,30,40 \mathrm{mg} / \mathrm{kg} /$ injection $)$ on each day (Houshyar et al, 2001a, b). After termination of morphine treatment, rats received either one injection of saline $12 \mathrm{~h}$ after their final morphine injection $(12 \mathrm{~h}$ withdrawal) or they continued to receive twice-daily injections of saline for 8 additional days (8-day withdrawal) (Table 1). As a control, for each of the above morphine treatment groups, a group of rats was treated with the vehicle saline twice daily for either 4 (12-h control) or 12 (8day control) consecutive days. Within each of the above treatment groups, rats were decapitated (A) at 0700 (time $=0 \mathrm{~min}$ ) under basal conditions, (B) at 1100 (time$=240 \mathrm{~min}$ ) after exposure to repeated tail bleeding, or (C) at 1100 (time $=240 \mathrm{~min}$ ) after exposure to $30 \mathrm{~min}$ restraint stress and repeated tail bleeding.

\section{Acute Stress: Tail Bleeding and Restraint}

In the animal room, on the final experimental day, a third of the rats within each group were immediately decapitated under basal conditions (time $=0 \mathrm{~min}$ ). The other two-thirds of the rats within each treatment group were exposed to tail bleeding $\pm 30 \mathrm{~min}$ restraint stress. For tail bleeding, rats were removed from their home cages and within $2 \mathrm{~min}$ a blood sample (time 0$)$ was collected from a cut $(\sim 1 \mathrm{~mm})$ made across the tip of the tail. These samples were considered to reflect basal conditions. Rats in the 'tail nick only' group were immediately returned to their home cages, whereas rats in the 'tail nick + restraint' group were placed in restraint tubes. Exposure to restraint was terminated 30 min after initiation of this stressor, at which time rats were returned to their home cages. In both groups, blood was collected by gently dislodging the formed clot at 15,30 , 60,90 , and 120 min after the initial tail nick. Samples of $240 \mu \mathrm{l}$ were collected using heparinized Natelson blood

Table I Experimental Groups ( $n=4$ Rats/Group)

\begin{tabular}{llll}
\hline Experiment & Treatment & Withdrawal & Stress groups \\
\hline $\mathbf{4}$ & $\begin{array}{l}4 \text { day morphine } \\
4 \text { day vehicle }\end{array}$ & $12 \mathrm{~h}$ withdrawal & Basal, tail nick, restraint \\
2 & $\begin{array}{l}\text { 4 day } \\
\text { morphine }+8\end{array}$ & $\begin{array}{l}\text { withdrawal } \\
\text { day vehicle }\end{array}$ & Basal, tail nick, restraint \\
& 12 day vehicle & 8 day control tail nick, restraint & \\
& & Basal, tail nick, restraint \\
\hline
\end{tabular}


collecting tubes (Fisher Scientific, Pittsburgh, PA) and kept at $4^{\circ} \mathrm{C}$ until centrifuged in the cold; plasma was aliquoted and frozen until analysis.

\section{Physiological Measures}

Body weight and food intake were recorded twice daily at 0700 and 1900 during the times of drug (morphine/vehicle) administration. At the end of experiments, rats were decapitated and trunk blood was collected for determination of hormone concentrations. In addition, epidydimal, mesenteric, perirenal, and subcutaneous white adipose tissues (WAT) as well as adrenals and thymuses were dissected, cleaned, and weighed.

\section{Radioimmunoassays}

All plasma hormone concentrations were measured using radioimmunoassays (RIA). Plasma corticosterone and testosterone concentrations were measured using RIA kits purchased from ICN Biomedicals (Costa Mesa, CA). RIA kits for determination of plasma insulin and leptin concentrations were purchased from Linco (St Charles, MO). Plasma ACTH concentrations were determined by an RIA that utilized a specific antiserum generously donated by Dr William England (University of Minnesota) at a dilution of $1: 120000$ and $\left[{ }^{125} \mathrm{I}\right] \mathrm{ACTH}$ (Diasorin, Stillwater, Minnesota) as labeled trace.

\section{In Situ Hybridization}

Brains were sectioned at $14 \mu \mathrm{m}$ in the coronal plane, and sections were collected onto Superfrost Plus Microscope Slides (Fisher Scientific) and were stored at $-80^{\circ} \mathrm{C}$ until further processing. In situ hybridization was conducted using techniques previously described (Viau et al, 2001). Briefly, sections were fixed with $4 \%$ paraformaldehyde for $5 \mathrm{~min}$ and then washed with PBS for 2 min on ice. Then sections were acetylated for $10 \mathrm{~min}(0.25 \%$ acetic anhydride in $0.1 \mathrm{M}$ triethanolamine- $0.9 \% \mathrm{NaCl} ; \mathrm{pH} 8.0$ ) at room temperature. Sections were then rinsed with $2 \times \mathrm{SSC}$, transferred through $70 \%$ ( $2 \mathrm{~min}), 95 \%$ ( $2 \mathrm{~min})$, and $100 \%$ ( $2 \mathrm{~min}$ ) ethanol, $100 \%$ chloroform $(5 \mathrm{~min})$, and $95 \%$ ethanol (2 min) and dried.

Hybridization histochemical localization of $\mathrm{CRH}$ and AVP mRNAs was performed using a ${ }^{33} \mathrm{P}$-labeled antisense cRNA probe transcribed from a full-length $(1.2 \mathrm{~kb})$ cDNA encoding $\mathrm{CRH}$ mRNA (courtesy of Dr $\mathrm{K}$ Mayo, Northwestern University, Evanston, IL) and a ${ }^{33} \mathrm{P}$-labeled antisense cRNA probe transcribed from a 230-bp cDNA fragment encoding the vasopressin-specific $3^{\prime}$ end (exon C) of AVP (a kind gift from Dr D Richter, University of Hamburg, Germany). The probes were labeled in a reaction mixture consisting of $1 \mu \mathrm{g}$ of linearized plasmid, $5 \times$ transcription buffer (Promega, Madison, WI), $5 \mu \mathrm{Ci}$ of ${ }^{33} \mathrm{P}$ rUTP, and $10 \mathrm{mM}$ of each ATP, CTP, and GTP, $100 \mathrm{mM}$ dithiothreitol, $40 \mathrm{U}$ RNase inhibitor, and $30 \mathrm{U}$ polymerase. The reaction was incubated for $2 \mathrm{~h}$ at $37^{\circ} \mathrm{C}$, and treated with DNase I for $15 \mathrm{~min}$ at $37^{\circ} \mathrm{C}$. Thereafter, the probe was separated from unincorporated nucleotides over a Micro Bio-Spin column (Bio Rad, Hercules, CA). The probe was diluted in hybridization buffer, and $100 \mu \mathrm{l}$ of diluted probe was applied to each slide to yield approximately $2 \times 10^{6} \mathrm{cpm}$ of labeled CRH or AVP probe per slide. Slides were then cover-slipped and incubated overnight at $55^{\circ} \mathrm{C}$. The next day, slides were dipped in $2 \times$ SCC to remove the coverslips. Thereafter, slides were washed with RNase A at $37^{\circ} \mathrm{C}$ for $30 \mathrm{~min}$ followed by a wash in RNase A buffer (consisting of $1 \mathrm{M}$ Tris, $5 \mathrm{M} \mathrm{NaCl}$, and $0.5 \mathrm{M}$ EDTA) without any RNase $\mathrm{A}$ for an additional $30 \mathrm{~min}$ at $37^{\circ} \mathrm{C}$. Next, slides were washed in $1 \times \mathrm{SSC}$ at room temperature followed by a wash in $0.5 \times \mathrm{SSC}$ for $30 \mathrm{~min}$ at $60^{\circ} \mathrm{C}$. Finally, slides were dehydrated in 70,95 , and $100 \%$ ethanol for 2 min each and air dried. Slides were then exposed to Hyperfilm MP (Amersham Pharmacia Biotech, Buckinghamshire, England) for $6 \mathrm{~h}$ (AVP), 4 days (CRF in PVN), or 7 days (CRF in CeA, Barr, BNST). Subsequently, slides were coated with Kodak NTB2 liquid autoradiographic emulsion (diluted 1 : 1; Eastman Kodak, Rochester, NY) and exposed at $4^{\circ} \mathrm{C}$ in the dark for $18 \mathrm{~h}$ (AVP), 12 days (PVN), or 21 days (CeA, Barr, BNST). Emulsion dipped slides were developed with Kodak D-19 for $5 \mathrm{~min}$, briefly rinsed in distilled water for $15 \mathrm{~s}$, fixed in Kodak fixer for $5 \mathrm{~min}$, and then washed in running water for $45 \mathrm{~min}$, all at room temperature. Slides were subsequently counterstained with cresyl violet, dehydrated in graded series of alcohol, placed in xylene, and coverslipped with Permount (Fisher Scientific, Pittsburg, $\mathrm{PA})$. All sections within the same brain region from control and experimental rats were hybridized at the same time.

Semiquantitative densitometric analyses of the relative level of AVP mRNA in the PVN and CRH mRNA in the anterior division of the BNST, the parvocellular region of the PVN, the central nucleus of the amygdala, and in Barrington's nucleus were performed using Macintoshdriven NIH Image software (Rasband, v. 1.61). This was assisted by landmarks made apparent with the cresyl violet staining. Optical density measurements in individual rats were determined from averaged readings of three sections showing the highest AVP or CRH mRNA levels and corrected for background. Analyses were performed blind to the identification of any group.

\section{Data Analysis}

Body weight (BW), food intake (FI), and caloric efficiency (CE) data are only displayed for experiment 2 , because the treatments and findings within the first 4 days of the experiment were similar between the two experimental groups. BW, FI, and CE were analyzed by one-way ANOVA with time (days) as the repeated measure and treatment as the main factor. Tukey honest significant difference (HSD) test was used to assess the effect of treatment within each experimental day (days 1-12) on BW, FI, and CE. Organ and fat depot weights as well as trunk plasma hormone concentrations were similar between the 'basal,' 'tail nick,' and 'restraint' (at $4 \mathrm{~h}$ after the stressor) groups within each treatment group, and therefore the data across these groups were combined. Organ and fat depot weights as well as trunk hormone concentrations were analyzed across experiments by two-way ANOVA, with treatment (vehicle and morphine) and withdrawal duration ( $12 \mathrm{~h}$ and 8 day) as the main factors, and within experiments by one-way ANOVA with treatment as the main factor. ACTH and 
corticosterone data were analyzed by two-way ANOVA, with time (min) as the repeated measure and treatment and withdrawal duration as the main factors. As appropriate, a one-way ANOVA for repeated measures was used to examine the effect of treatment, and the Tukey HSD test was used to assess the effect of treatment at each particular time point (BL, 15, 30, 60, 90, 120, and $240 \mathrm{~min}$ ). Hybridization signals were similar between the 'tail nick' and 'restraint' groups and therefore, the data from these groups were combined ('stress' group). The hybridization data were analyzed by two-way ANOVA with treatment and stress as main factors. Post hoc analysis was performed, when appropriate, using Tukey HSD test. All data are presented as mean \pm standard error of the mean (SEM). All statistical analysis was carried out using Statistica (v. 5.0; Satsoft, Tulsa, OK).

\section{RESULTS}

\section{Energy Balance}

Body weight. Body weight increased with time $(p<0.0001)$ in vehicle-treated rats, but not in morphine-treated rats (Treatment: $\mathrm{F}(1,20)=88.7, p<0.0001$; Time: $\mathrm{F}(22,440)=$ $84.5, \quad p<0.0001 ; \quad$ Treatment ${ }^{\star}$ Time: $\quad \mathrm{F}(22,440)=59.0$, $p<0.0001$ ) (Figure 1a). Furthermore, termination of morphine treatment induced a significant $(p<0.01)$ decrease in body weight $36 \mathrm{~h}$ after the final morphine injection, from which rats did not recover until 3 days.

Food intake. Food intake during the dark, but not the light, cycle was significantly reduced in morphine-treated compared to vehicle-treated rats (Treatment: $\mathrm{F}(1,20)=24.3$, $p<0.0001$; Time: $\mathrm{F}(21,420)=184.2, p<0.0001$; Treatment ${ }^{*}$ Time: $\mathrm{F}(21,420)=10.3, p<0.0001$ ) (Figure $1 \mathrm{~b}$ ). In addition, after the last of the repeated morphine injections, there was a further dramatic decrease $(p<0.0001)$ in food intake during the dark cycle, $36 \mathrm{~h}$ after the final injection, from which rats did not fully recover until the final treatment day.

Caloric efficiency. Caloric efficiency (grams of body weight gained/calories ingested) was significantly reduced in morphine-treated rats compared to vehicle-treated rats during drug treatment (Treatment: $\mathrm{F}(1,20)=70.0$, $p<0.0001$; Time: $\mathrm{F}(10,200)=8.9, p<0.0001$; Treatment ${ }^{*}$ Time: $\mathrm{F}(10,200)=10.1, p<0.0001$ ) (Figure 1c). In addition, termination of repeated morphine treatment precipitated a further decrease $(p<0.0001)$ in caloric efficiency, maximal at $36 \mathrm{~h}$ after the final morphine injection and recovering subsequently.

Leptin and insulin concentrations. Morphine dependence and withdrawal transiently decreased plasma leptin (Treatment: $\mathrm{F}(1,44)=8.5, p<0.01$; Withdrawal: $\mathrm{F}(1,44)=8.6$, $p<0.01$; Treatment ${ }^{\star}$ Withdrawal: $\mathrm{F}(1,44)=3.0$, NS) and insulin (Treatment: $\mathrm{F}(1,44)=8.6, p<0.01$; Withdrawal: $\mathrm{F}(1,44)=11.7, p<0.01$; Treatment ${ }^{*}$ Withdrawal: $\mathrm{F}(1,44)=$ 0.45 , NS) (Figure $2 \mathrm{a}$ and $\mathrm{b}$, respectively). Plasma leptin $(\mathrm{F}(1,22)=20.8, \quad p<0.001)$ and insulin $(\mathrm{F}(1,22)=6.1$,

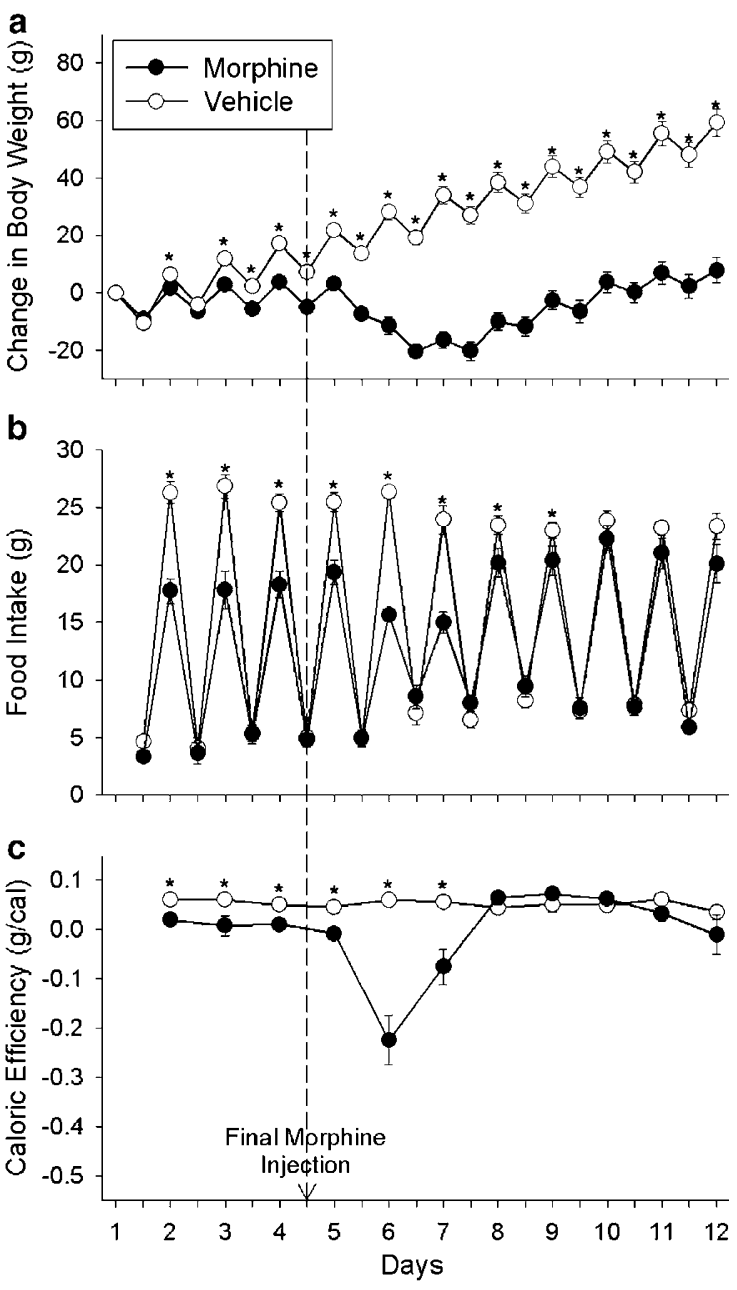

Figure I Intermittent morphine treatment and withdrawal from morphine reduced body weight gain (a), food intake (b), and caloric efficiency (c). Marked decreases occurred at $36 \mathrm{~h}$, the time of peak withdrawal; thereafter, the rats recovered. Rats received twice-daily injections of morphine ( $10-40 \mathrm{mg} / \mathrm{kg}$, s.c.) for 4 consecutive days followed by 8 days of saline injections twice daily. The control group was treated twice daily with the vehicle saline throughout. Measurements of body weight and food intake were made every $12 \mathrm{~h}$, caloric efficiency was calculated once daily in the morning. Nocturnally active rats weigh more in the morning and less in the evening, and eat most during the dark period. Only during the dark, but not the light period, was food intake significantly reduced with morphine dependence and withdrawal. The dashed line indicates the time of final morphine injection. The results are expressed as means $\pm \operatorname{SEM}(n=12$ rats/group). $* 0<0.05$ indicates effect of morphine vs saline treatment.

$p<0.05)$ concentrations were significantly reduced $12 \mathrm{~h}$ after the final morphine injection; 8 days after the end of morphine treatment, plasma leptin and insulin concentrations had recovered in morphine-treated rats to levels in vehicle-treated rats.

White fat depot weights. Morphine dependence and withdrawal did not significantly affect the relative weights of any of the white adipose depots evaluated, and although absolute values were decreased in morphine-treated rats, they maintained normal relationships with body weight (Table 2). 


\section{Gonadal Activity}

Testosterone concentrations. Plasma testosterone concentrations serve as an index of the effects of stress on the hypothalamo-pituitary-gonadal axis; activity in this system is inhibited by many, but not all chronic stressors (Dallman et al, 2002). Morphine dependence and withdrawal transiently decreased plasma testosterone concentrations
$12 \mathrm{~h}$

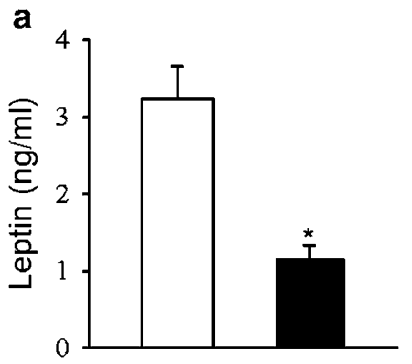

b
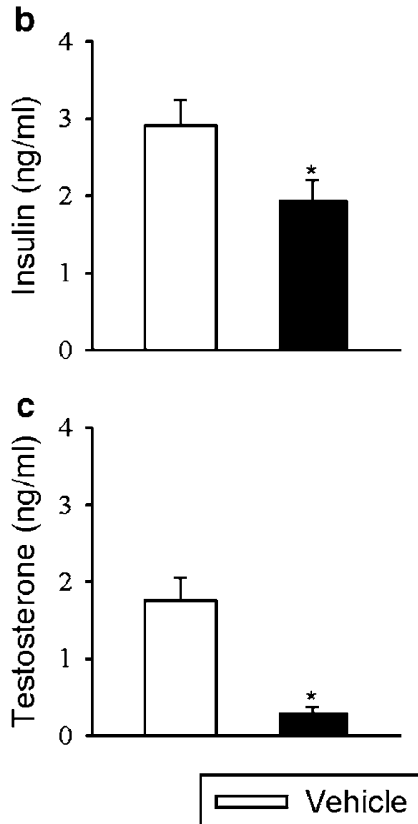

Figure 2 Plasma leptin (a), insulin (b), and testosterone (c) concentrations were reduced in morphine-treated rats $12 \mathrm{~h}$ after the final morphine injection but had recovered 8 days later. The results are expressed as means $\pm \operatorname{SEM}(n=12$ rats/group). $* p<0.05$ indicates effect of morphine $v s$ saline treatment.
(Treatment: $\mathrm{F}(1,44)=11.8, p<0.01$; Withdrawal: $\mathrm{F}(1,44)=$ 12.0, $p<0.01$; Treatment ${ }^{*}$ Withdrawal: $\left.\mathrm{F}(1,44)=0.0, \mathrm{NS}\right)$ (Figure 2c). Plasma testosterone concentrations were significantly reduced $12 \mathrm{~h}$ after the final morphine injection $(\mathrm{F}(1,22)=22.0, p<0.0001)$. After 8 days, testosterone had recovered to values observed in vehicle-treated rats.

\section{Pituitary-Adrenal Activity}

Adrenal and thymus weights. Adrenal weight serves as an integrated measure of ACTH secretion over time (Jacobson et al, 1989). Morphine dependence and withdrawal significantly affected relative adrenal weight (Treatment: $\mathrm{F}(1,44)=53.0, p<0.0001$; Withdrawal: $(1,44)=374.0$, $p<0.0001$; Treatment ${ }^{\star}$ Withdrawal: $\left.(1,44)=27.2, p<0.0001\right)$ (Figure 3a). At $12 \mathrm{~h}$ after the final morphine injection, relative adrenal weights were significantly elevated in morphine-treated rats $(\mathrm{F}(1,22)=61.0, p<0.001)$, suggesting a history of elevated ACTH secretion. However, 8 days after termination of morphine treatment, relative adrenal weights were similar between vehicle- and morphine-treated rats, suggesting normalization of ACTH within that period. Thymus weight serves as an integrated measure of inhibitory glucocorticoid action (Akana et al, 1985). Morphine withdrawal also significantly affected relative thymus weight (Treatment: $\mathrm{F}(1,44)=1.2$, NS; Withdrawal: $(1,44)=41.5, p<0.0001$; Treatment ${ }^{\star}$ Withdrawal: $(1,44)=$ 9.0, $p<0.01$ ) (Figure 3a). At $12 \mathrm{~h}$ after the last morphine injection, relative thymus weights were similar between vehicle- and morphine-treated rats (Figure $3 \mathrm{~b}$ ). However, 8 days after termination of morphine treatment, relative thymus weights were significantly reduced in morphinetreated rats compared with vehicle-treated controls $(\mathrm{F}(1,22)=9.0, p<0.001)$.

ACTH and corticosterone responses $12 \mathrm{~h}$ after the last morphine injection. Basal plasma ACTH was similar between vehicle- and morphine-treated rats $12 \mathrm{~h}$ after the last morphine injection (Figure $4 \mathrm{a}$ and $\mathrm{b}$ ). Acute exposure to restraint produced significant increases in plasma ACTH concentrations in both vehicle-treated (Treatment: $\mathrm{F}(1,6)=11.1, \quad p<0.05 ;$ Time: $\mathrm{F}(6,36)=13.6, \quad p<0.0001$; Treatment ${ }^{*}$ Time: $\left.\mathrm{F}(6,36)=7.9, p<0.001\right)$ and $12 \mathrm{~h}$ morphine withdrawn (Treatment: $\mathrm{F}(1,6)=p<0.001$; Time: $\mathrm{F}(6,36)=35.5, p<0.0001$; Treatment ${ }^{*}$ Time: $\mathrm{F}(6,36)=14.0$, $p<0.0001)$ rats. However, the ACTH responses to both tail nick alone (Treatment: $\mathrm{F}(1,6)=9.3, \quad p<0.05$; Time: $\mathrm{F}(6,36)=12.8, \quad p<0.0001$; Treatment ${ }^{*}$ Time: $\mathrm{F}(6,36)=4.0$,

Table 2 Effects of Intermittent Morphine Treatment during Early ( $12 \mathrm{~h}$ ) and Late (8 days) Withdrawal on White Adipose Depots ( $n=12$ Rats/Group)

\begin{tabular}{|c|c|c|c|c|}
\hline \multirow{2}{*}{$\begin{array}{l}\text { Experiment } \\
\text { Treatment }\end{array}$} & \multicolumn{2}{|c|}{ I 2 h withdrawal } & \multicolumn{2}{|c|}{8 days withdrawal } \\
\hline & Vehicle (g/l00 g BW) & Morphine (g/l00 g BW) & Vehicle (g/l00 g BW) & Morphine (g/l00 g BW) \\
\hline Epidydimal & $0.42 \pm 0.06$ & $0.38 \pm 0.05$ & $0.57 \pm 0.04$ & $0.52 \pm 0.04$ \\
\hline Perirenal & $0.38 \pm 0.03$ & $0.32 \pm 0.03$ & $0.49 \pm 0.03$ & $0.44 \pm 0.03$ \\
\hline Mesenteric & $1.66 \pm 0.07$ & $1.47 \pm 0.07$ & $1.67 \pm 0.07$ & $1.55 \pm 0.06$ \\
\hline Subcutaneous & $0.82 \pm 0.06$ & $0.78 \pm 0.05$ & $0.69 \pm 0.04$ & $0.64 \pm 0.04$ \\
\hline
\end{tabular}


$12 \mathrm{~h}$

8 day

a
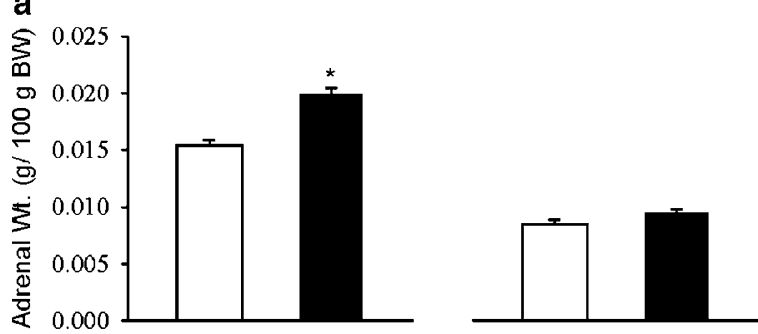

b

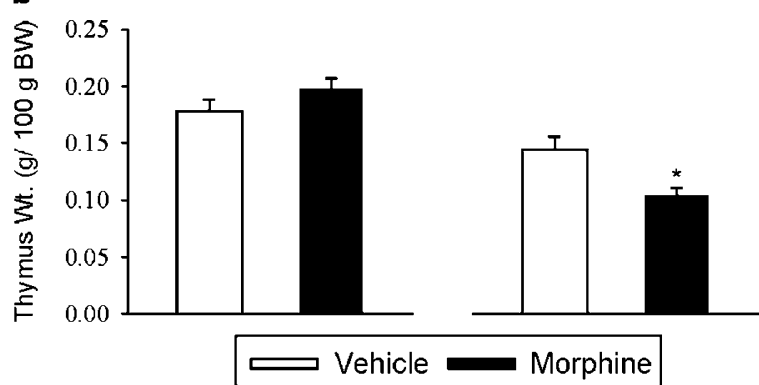

Figure 3 Adrenal weight (a) was increased in morphine-treated rats $12 \mathrm{~h}$ after final injection and recovered within 8 days after the last injection, whereas thymus weight (b) was decreased in morphine-treated rats 8 days after the final injection but normal $12 \mathrm{~h}$ after the final morphine injection. The results are expressed as means \pm SEM ( $n=12$ rats/group). ${ }^{*} p<0.05$ indicates effect of morphine vs saline treatment.

$p<0.01$ ) and tail nick + restraint stress (Treatment: $\mathrm{F}(1,6)=10.7, \quad p<0.05$; Time: $\mathrm{F}(6,36)=37.9, \quad p<0.0001$; Treatment ${ }^{*}$ Time: $\left.\mathrm{F}(6,36)=4.2, p<0.01\right)$ were significantly greater in morphine-treated rats $12 \mathrm{~h}$ after the last morphine injection compared with vehicle-treated rats.

Initial corticosterone concentrations were also similar between vehicle- and morphine-treated rats $12 \mathrm{~h}$ after the final morphine injection (Figure $4 \mathrm{c}$ and $\mathrm{d}$ ). Acute restraint resulted in a significant increase in plasma corticosterone levels in vehicle-treated (Treatment: $\mathrm{F}(1,6)=3.5$, NS; Time: $\mathrm{F}(6,36)=46.4, p<0.0001$; Treatment ${ }^{\star}$ Time: $\mathrm{F}(6,36)=3.1$, $p<0.05$ ), but not morphine-treated rats (Treatment: $\mathrm{F}(1,6)=2.1$, NS; Time: $\mathrm{F}(6,36)=23.7, p<0.0001$; Treatment ${ }^{\star}$ Time: $\left.F(6,36)=1.8, \mathrm{NS}\right)$. Morphine-treated rats demonstrated an enhanced corticosterone response to tail nick alone as compared to vehicle-treated rats (Treatment: $\mathrm{F}(1,6)=2.7$, NS; Time: $\mathrm{F}(6,36)=43.8, p<0.0001$; Treatment ${ }^{\star}$ Time: $\left.F(6,36)=2.4, p<0.05\right)$. However, unlike the ACTH response, $12 \mathrm{~h}$ after the final morphine injection, morphine-treated rats did not have a significantly greater corticosterone response to restraint as compared with the vehicle-treated control (Treatment: $\mathrm{F}(1,6)=3.5$, NS; Time: $\mathrm{F}(6,36)=25.7, p<0.0001$; Treatment ${ }^{*}$ Time: $\mathrm{F}(6,36)=0.7$, NS).

ACTH and corticosterone responses 8 days after the last morphine injection. Basal plasma ACTH was similar between vehicle- and morphine-treated rats (Figure 5a and $b$ ). As expected, restraint produced significant increases in plasma ACTH in vehicle-treated rats (Treatment: $\mathrm{F}(1,6)=4.5$, NS; Time: $\mathrm{F}(6,36)=15.6, p<0.0001$; Treat-
Tail Nick

Tail Nick+Restraint

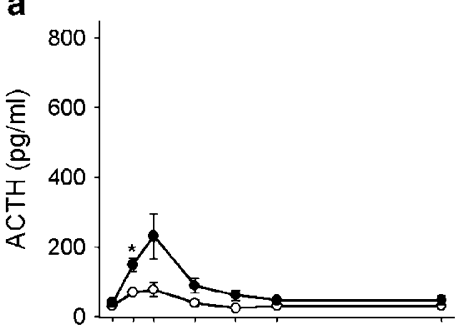

C

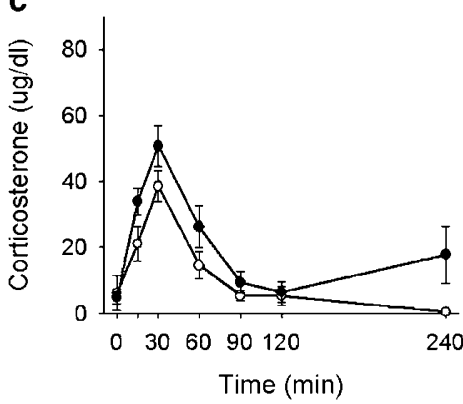

b

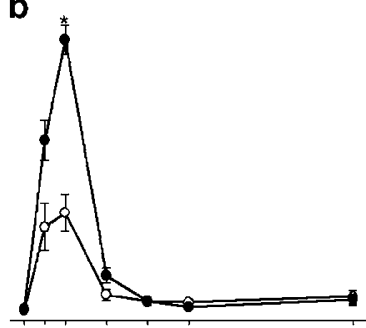

d

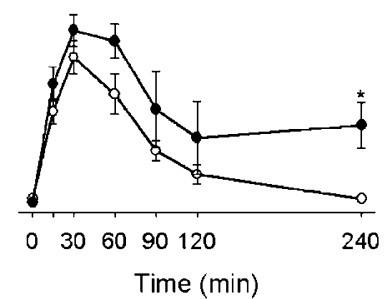

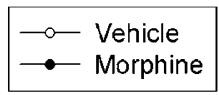

Figure 4 The ACTH response to the acute, novel stress of tail nick \pm 30 min restraint and the corticosterone response to tail nick alone were significantly facilitated in morphine-treated rats $12 \mathrm{~h}$ after their final morphine injection. Rats received twice-daily injections of saline or morphine for 4 consecutive days. On day 5, the ACTH and corticosterone responses to tail nick alone (a and c, respectively) or tail nick +30 min restraint ( $b$ and $d$, respectively) were examined. Restraint stress was initiated immediately after the initial tail nick at 0 min and lasted 30 min. Blood was collected under basal conditions ( 0 min) as well as 15, 30, 60, 90, 120, and $240 \mathrm{~min}$ after the initial tail nick. The results are expressed as means \pm SEM ( $n=4$ rats/group). ${ }^{*} p<0.05$ indicates effect of morphine vs saline treatment.

ment ${ }^{*}$ Time: $\left.\mathrm{F}(6,36)=5.8, p<0.001\right)$. However, rats that had been previously treated with morphine and then treated with saline for 8 days did not display a significant ACTH response to restraint (Treatment: $\mathrm{F}(1,6)=0.5$, NS; Time: $\mathrm{F}(6,36)=3.8, p<0.01$; Treatment ${ }^{*}$ Time: $\left.\mathrm{F}(6,36)=1.5, \mathrm{NS}\right)$. ACTH responses to tail nick \pm restraint stress were similar between vehicle-treated rats and rats undergoing chronic morphine withdrawal, although there was a trend toward a reduced ACTH response to restraint in rats that had been morphine-treated (tail nick: Treatment: $\mathrm{F}(1,6)=0.0, \mathrm{NS}$; Time: $\mathrm{F}(6,36)=1.8, \mathrm{NS}$; Treatment ${ }^{*}$ Time: $\mathrm{F}(6,36)=1.8$, NS; tail nick + restraint: Treatment: $\mathrm{F}(1,5)=1.3$, NS; Time: $\mathrm{F}(6,30)=15.9, p<0.0001$; Treatment ${ }^{*}$ Time: $\mathrm{F}(6,30)=3.06$, $p=0.06)$.

Basal corticosterone concentrations were similar in vehicle- and morphine-treated rats undergoing 8-day morphine withdrawal (Figure $5 \mathrm{c}$ and $\mathrm{d}$ ). Acute exposure to restraint produced significant increases in plasma corticosterone concentrations in both vehicle-treated (Treatment: $\mathrm{F}(1,6)=3.9, \quad \mathrm{NS}$; Time: $\mathrm{F}(6,36)=31.8$, $p<0.0001$; Treatment ${ }^{*}$ Time: $\left.\mathrm{F}(6,36)=6.1, p<0.001\right)$ and 8-day morphine withdrawn (Treatment: $\mathrm{F}(1,6)=13.7$, $p<0.05$; Time: $\mathrm{F}(6,36)=18.0, p<0.0001$; Treatment ${ }^{\star}$ Time: $\mathrm{F}(6,36)=4.0, p<0.01)$ rats. There were no significant 

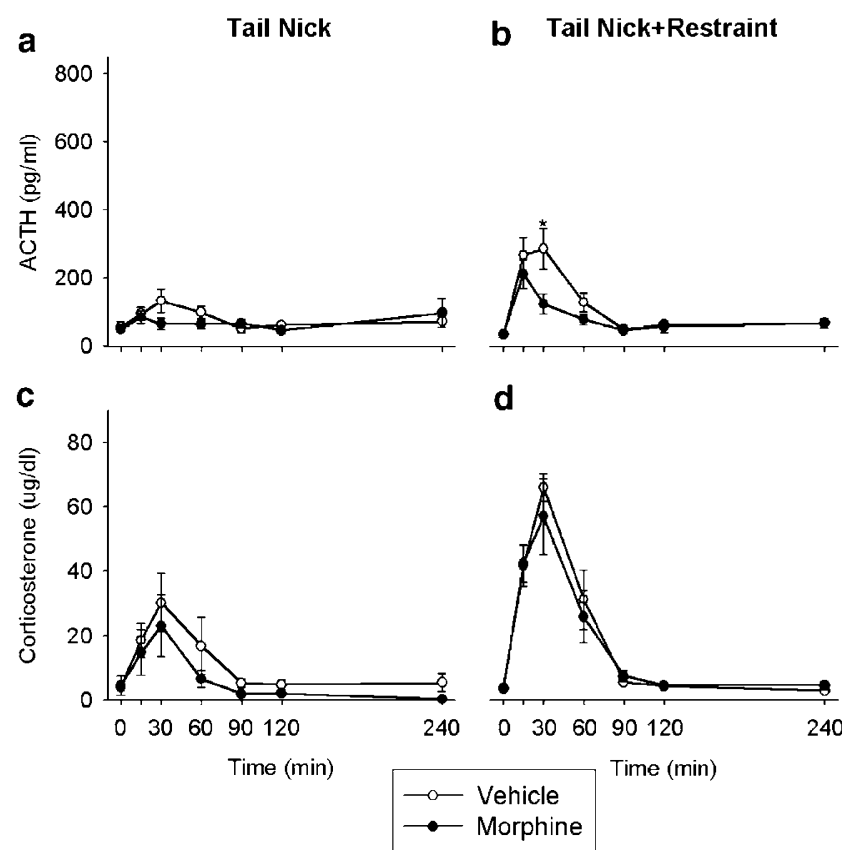

Figure 5 The $\mathrm{ACTH}$ and corticosterone responses to the acute, novel stress of tail nick \pm 30 min restraint were similar between morphine- and saline-treated rats 8 days after the final morphine injection, although there was a trend toward a reduced $\mathrm{ACTH}$ response to tail nick alone in morphine-treated rats. Rats received twice-daily injections of saline or morphine for 4 consecutive days followed by 8 additional days of saline injections in both treatment groups. On day 13 , the ACTH and corticosterone responses to tail nick alone ( $\mathrm{a}$ and $\mathrm{c}$, respectively) or tail nick +30 min restraint ( $b$ and $d$, respectively) were examined. Restraint stress was initiated immediately after the initial tail nick at 0 min and lasted $30 \mathrm{~min}$. Blood was collected under basal conditions ( $0 \mathrm{~min})$ as well as 15 , 30, 60, 90, 120, and $240 \mathrm{~min}$ after the initial tail nick. The results are expressed as means \pm SEM ( $n=4$ rats/group). $* 0<0.05$ indicates effect of morphine vs saline treatment.

differences in corticosterone responses to tail nick \pm restraint between vehicle- or morphine-treated rats, showing that the hyper-responsivity of the HPA axis observed $12 \mathrm{~h}$ after the final morphine injection did not persist for 8 days (tail nick: Treatment: $\mathrm{F}(1,6)=1.3$, NS; Time: $\mathrm{F}(6,36)=8.1$, $p<0.0001$; Treatment ${ }^{\star}$ Time: $\mathrm{F}(6,36)=0.3$, NS; tail nick + restraint: Treatment: $\mathrm{F}(1,6)=0.2$, NS; Time: $\mathrm{F}(6,36)=45.4$, $p<0.0001$; Treatment ${ }^{\star}$ Time: $\left.\mathrm{F}(6,36)=0.4, \mathrm{NS}\right)$.

\section{CRF and AVP mRNA $12 \mathrm{~h}$ after Last Morphine Injection}

Overall, intermittent morphine treatment and stress (tail nick \pm restraint) significantly altered CRF mRNA levels in the PVN (Treatment: $\mathrm{F}(1,18)=4.63, \quad p<0.05$; Stress: $\mathrm{F}(1,18)=11.3, p<0.01$; Treatment ${ }^{*}$ Stress: $\mathrm{F}(1,18)=0.44$, NS) (Figures 6a-d and 8a). Under basal conditions, there was a tendency $(p=0.07)$ toward increased levels of CRF mRNA in the PVN in morphine-treated rats compared to vehicle-treated rats (Figure 6a and $b$ ). Exposure to stress significantly increased CRF mRNA levels in the PVN in both vehicle- and morphine-treated rats (both $p<0.05$ ). Furthermore, stress-induced levels of CRF mRNA were significantly greater in morphine- compared to vehicle-treated rats $(p<0.05)$ (Figure $6 c$ and $d)$.

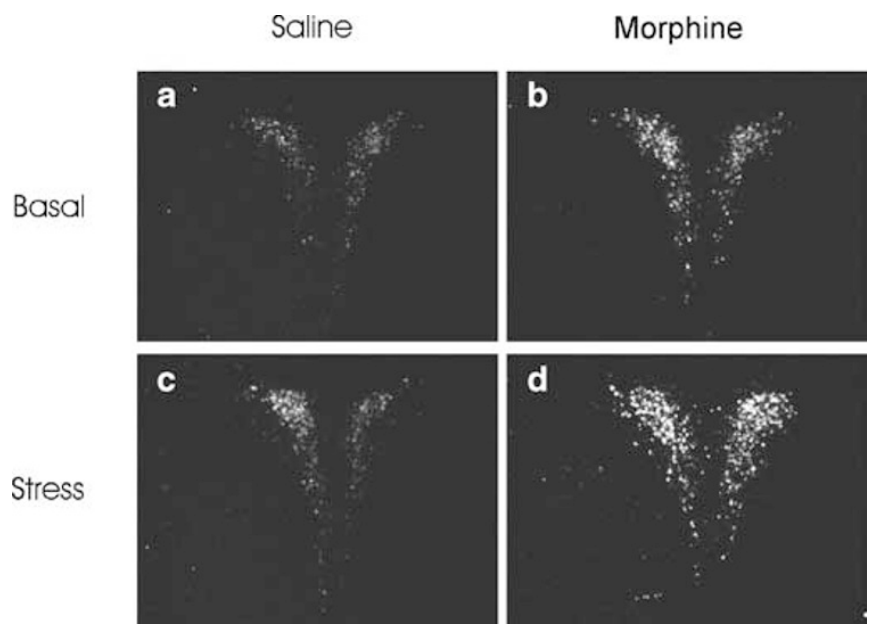

Figure 6 Darkfield photomicrographs of CRF mRNA responses in the PVN. CRF mRNA expression in morphine-treated rats (b, $d$ ) was elevated under basal conditions ( $a, b)$ and after stress (c, d) as compared with vehicle-treated rats $(a, c)$. Sections were selected to represent the mean responses shown in Figure 8.
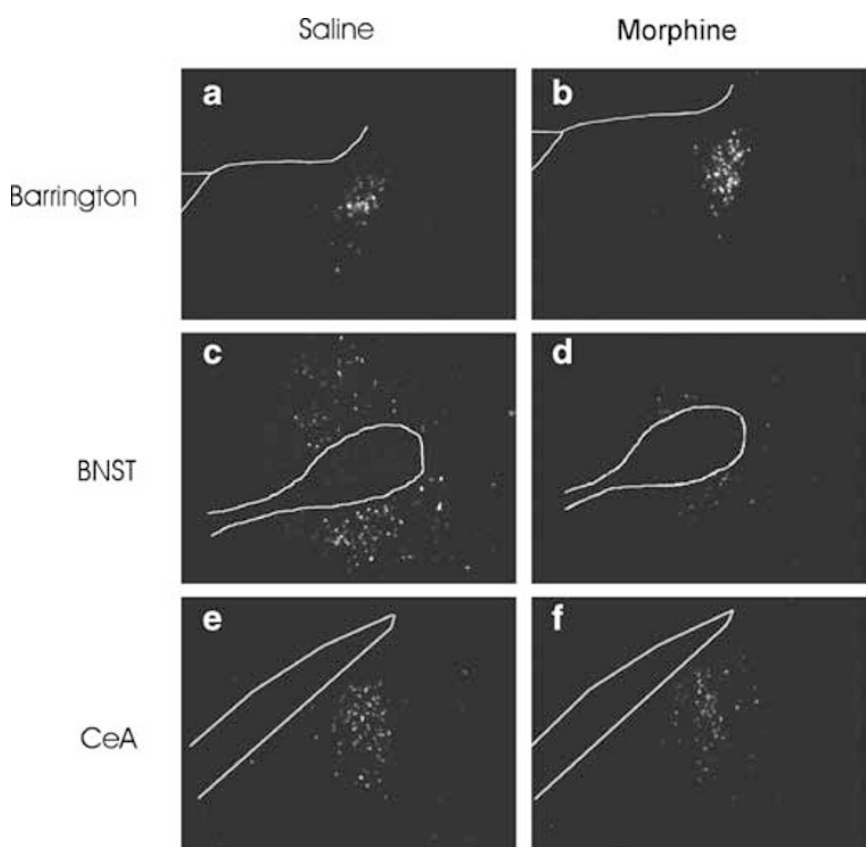

Figure 7 Darkfield photomicrographs of CRF mRNA responses in the Barrington's nucleus, BNST, and CeA. Under 'basal' conditions, CRF mRNA expression in morphine-treated rats was elevated in Barrington's nucleus (b), decreased in the BNST (d), and unchanged in the CeA ( $f$ ), compared with saline-treated rats $(a, c, e)$. Sections were selected to represent the mean responses shown in Figure 8.

Overall, intermittent morphine treatment significantly altered CRF mRNA levels in Barrington's nucleus (Treatment: $\mathrm{F}(1,20)=5.4, \quad p<0.05 ; \quad$ Stress: $\mathrm{F}(1,20)=1.7$, NS; Treatment ${ }^{\star}$ Stress: $\mathrm{F}(1,20)=2.9$, NS) (Figures $7 \mathrm{a}, \mathrm{b}$ and $8 \mathrm{~b}$ ). Under basal conditions, the level of CRF mRNA was significantly increased in morphine-treated rats compared to the vehicle-treated controls $(p<0.01)$. Exposure to stress 

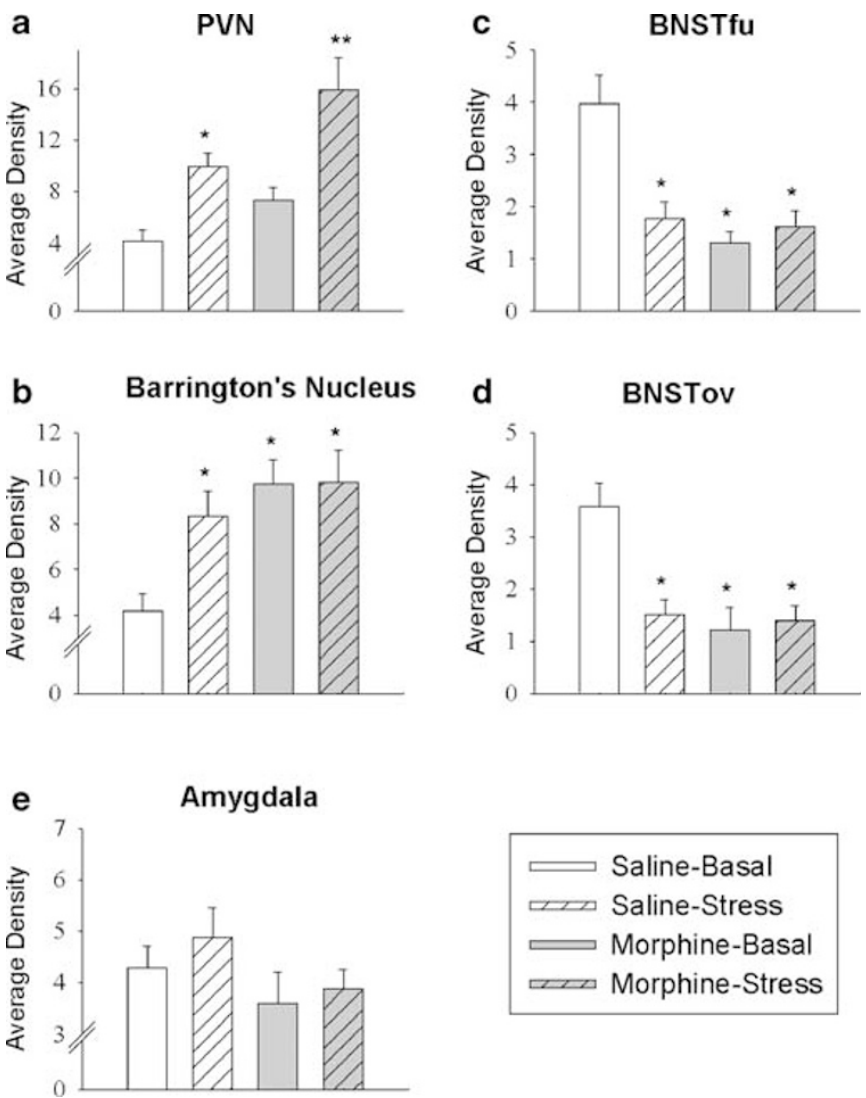

Figure 8 CRF mRNA expression was increased in the PVN (a) and Barrington's nucleus (b), decreased in the BNST oval (c) and fusiform (d) nuclei, and unchanged in the CeA (e) in morphine-treated rats under 'basal' conditions $12 \mathrm{~h}$ after their final morphine injection. Stress-induced increases in CRF mRNA expression in the PVN were increased further in the morphine-treated rats, whereas stress-induced changes in expression of CRF mRNA in the other structures were similar in the two groups of rats. The results are expressed as means \pm SEM ( $n=4-8$ rats/group). $* p<0.05$ indicates a significant difference from the saline-basal group; $* * * 0.05$ indicates a significant difference from the saline-basal, saline-stress, and morphine-basal groups.

significantly increased CRF mRNA in Barrington's nucleus in vehicle-treated rats $(p<0.01)$ to values similar to those observed in morphine-treated rats under basal conditions. Stress exposure did not produce a further increase in CRF mRNA in morphine-treated rats. Thus, the levels of CRF mRNA in Barrington's nucleus under conditions of stress were similar between vehicle- and morphine-treated rats as a consequence of the control rats responding and the morphine-treated rats not responding to tail nick \pm restraint.

The effects of intermittent morphine treatment and stress on CRF mRNA expression in the fusiform (Figure 8c) and oval (Figure 8d) nuclei of the BNST were similar (Figure 7c and $\mathrm{d}$ ). In both nuclei, intermittent treatment with morphine and stress significantly altered CRF mRNA levels in the BNST (BNST fusiform: Treatment: $\mathrm{F}(1,20)=14.08$, $p<0.01$; Stress: $\mathrm{F}(1,20)=6.2, p<0.05$; Treatment ${ }^{\star}$ Stress: $\mathrm{F}(1,20)=11.4, p<0.01$; BNST oval: Treatment: $\mathrm{F}(1,20)=$ 11.0, $p<0.01$; Stress: $\mathrm{F}(1,20)=6.3, p<0.05$; Treatment ${ }^{*}$ Stress: $\mathrm{F}(1,20)=9.2, p<0.01)$. Under basal conditions, CRF
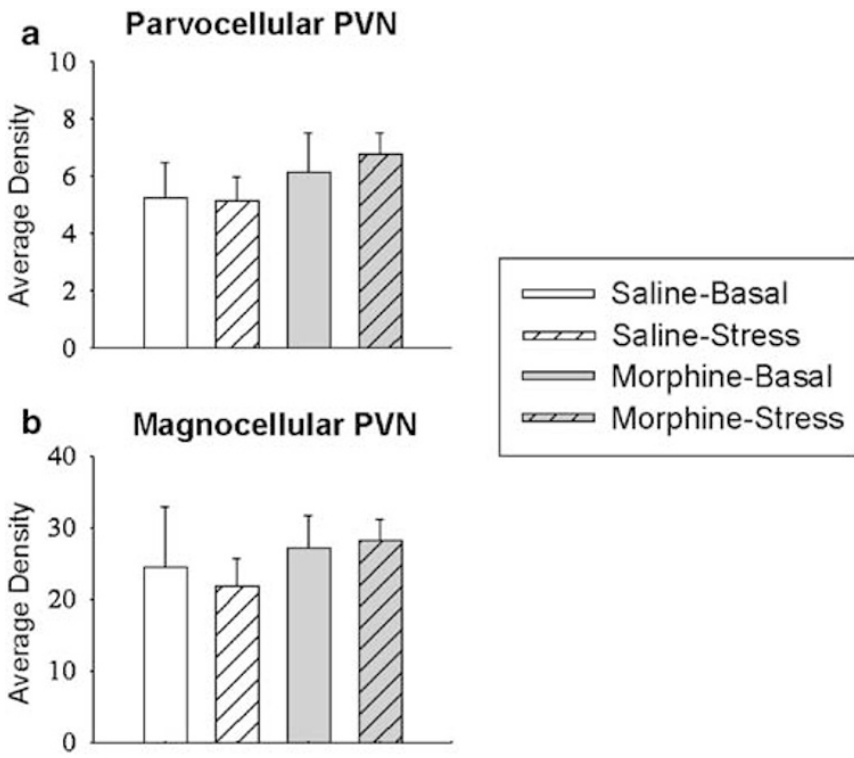

Figure 9 AVP mRNA expressions in parvocellular (a) and magnocellular (b) cells of the PVN were not affected by morphine treatment or exposure to the acute, novel stress of tail nick \pm 30 min restraint. The results are expressed as means \pm SEM ( $n=4-8$ rats/group).

mRNA levels in the BNST were significantly decreased in morphine-treated rats compared to the vehicle controls $(p<0.01)$. Exposure to stress significantly reduced CRF mRNA levels in vehicle-treated rats to values observed in morphine-treated rats under basal conditions $(p<0.01)$. Stress exposure did not result in a further reduction in CRF mRNA levels in morphine-treated rats. Thus, CRF mRNA in the oval and fusiform nuclei of the BNST under stress conditions was similar in vehicle- and morphine-treated rats.

Neither intermittent morphine treatment nor exposure to stress significantly altered CRH mRNA expression in the central nucleus of the amygdala (Figures $7 \mathrm{e}, \mathrm{f}$ and $8 \mathrm{e}$ ).

Neither intermittent morphine treatment nor exposure to stress significantly altered AVP mRNA expression in either the magnocellular or the parvocellular cells of the PVN (Figure $9 \mathrm{a}$ and $\mathrm{b}$ ).

\section{DISCUSSION}

At $12 \mathrm{~h}$ after the last injection of morphine, rats revealed most aspects of altered physiology that are common to repeated or chronic stressors. Changes in energy balance revealed the characteristic signature of chronic stress, central CRF cell groups exhibited altered activity, testosterone was decreased, and HPA axis responsivity to novel stimuli was increased (Dallman et al, 2002). There was marked recovery with time after morphine withdrawal, such that by 8 days after a short, 4-day regimen of morphine b.i.d., food intake, body weight, hormones and stress responsivity had recovered. However, because it is a chronic stressor, intermittent morphine treatment may itself cause vulnerability to relapse. The data are summarized in Table 3. 
Table 3 Summary of the Effects of Intermittent Morphine Treatment during early $(12 \mathrm{~h}$ ) and Late (8 days) Withdrawal on Energy Balance and HPA Activity. The Effects of Early and Late Withdrawal are Compared to the Responses Observed in the Appropriate Control (Vehicle-treated) Group

\begin{tabular}{|c|c|c|}
\hline & $\begin{array}{l}\text { Early }(12 \mathrm{~h}) \\
\text { withdrawal }\end{array}$ & $\begin{array}{c}\text { Late (8 days) } \\
\text { withdrawal }\end{array}$ \\
\hline Body weight & $\downarrow \downarrow$ & $\downarrow$ \\
\hline Food intake & $\downarrow \downarrow$ & $=$ \\
\hline Caloric efficiency & $\downarrow \downarrow$ & $=$ \\
\hline Leptin concentration & $\downarrow \downarrow$ & $=$ \\
\hline Insulin concentration & $\downarrow \downarrow$ & $=$ \\
\hline White fat depot weights & $=$ & $=$ \\
\hline Testosterone concentration & $\downarrow \downarrow$ & $=$ \\
\hline Adrenal size & $\uparrow \uparrow$ & $=$ \\
\hline Thymus size & $=$ & $\downarrow \downarrow$ \\
\hline Basal ACTH & $=$ & $=$ \\
\hline Stress ACTH & $\uparrow \uparrow$ & $=\downarrow$ \\
\hline Basal corticosterone & $=$ & $=$ \\
\hline Stress corticosterone & $=\uparrow$ & $=$ \\
\hline Basal PVN CRF mRNA & $=\uparrow$ & ND \\
\hline Stress PVN CRF mRNA & $\uparrow \uparrow$ & ND \\
\hline Basal Barrington CRF mRNA & $\uparrow \uparrow$ & ND \\
\hline Stress Barrington CRF mRNA & $=$ & ND \\
\hline Basal BNST CRF mRNA & $\downarrow \downarrow$ & ND \\
\hline Stress BNST CRF mRNA & $=$ & ND \\
\hline Basal and stress amygdala CRF mRNA & $=$ & ND \\
\hline Basal and stress PVN AVP mRNA & $=$ & ND \\
\hline
\end{tabular}

$\downarrow, \uparrow$, and $=$ indicate reduced, increased, or equal response compared with the control group. A single arrow indicates a slight change relative to control, whereas two arrows indicate a more dramatic difference from the control response. ND indicates not determined.

\section{Energy Balance}

Consistent with previous findings, morphine dependence reduced body weight gain, and withdrawal $36 \mathrm{~h}$ after the last injection decreased body weight further (Boghossian et al, 2001; Houshyar et al, 2001a; Langerman et al, 2001; Levine et al, 1988). The reduction in body weight gain was paralleled by a marked attenuation of food intake by morphine-treated rats. It has been shown that morphine has a triphasic effect on food intake, inducing initial, brief hypophagia followed by hyperphagia and then persistent hypophagia, that results in an overall reduction in food intake during $24 \mathrm{~h}$ (Boghossian et al, 2001; Leshem, 1988). However, reduced food intake was not solely responsible for reduced weight gain in morphine-treated rats, caloric efficiency was also diminished.

Caloric efficiency (mg wt gain/kcal eaten) was reduced during morphine treatment, and the abrupt cessation of morphine injections precipitated a marked decrease in caloric efficiency $36 \mathrm{~h}$ after the last injection. The reduced caloric efficiency in morphine-treated rats was probably a consequence of increased sympathetic neuronal outflow (Akana et al, 1999). Reduced plasma insulin and leptin concentrations also suggest increased sympathetic activity in morphine-treated rats (Bartness, 1998; Rayner and Trayhurn, 2001). In support of this, previous studies have shown that opioid dependence and withdrawal are associated with increased noradrenergic and catecholaminergic activity in brain and hypothalamus (Ahtee et al, 1989; Fuertes et al, 2000; Milanes et al, 1993, 1997, 1998).

Reduced caloric efficiency in morphine-treated rats may be related to elevated hypothalamic CRF mRNA expression in these animals. Many have shown that CRF injected into the brain reduces body weight, food intake, and caloric efficiency (Buwalda et al, 1997; Shibasaki et al, 1988; Smagin et al, 1999). Thus, it is likely that some of the effects of morphine on energy balance are mediated through the central actions of CRF on stimulation of sympathetic outflow (Brown et al, 1981; Fisher et al, 1982). Recovery of caloric efficiency 8 days after intermittent morphine treatment was associated with normalization of circulating leptin and insulin concentrations, suggesting recovery of normal sympathetic activity. We did not measure central CRF expression in those rats, but the near-normalization of pituitary-adrenal activity under basal and stress conditions at this time suggests that central CRF activity in opioid withdrawn rats may have been restored.

The effects of morphine on energy balance are similar to responses observed when animals are exposed to chronic or repeated stressors and provide further evidence that the paradigm induces activity in the central stress network (Dallman et al, 2002). Many studies have shown that chronic stress reduces body weight, food intake, and caloric efficiency (Dallman, 2001). Furthermore, chronic stressors (eg intermittent cold or restraint), like intermittent morphine treatment, reduce plasma leptin and insulin concentrations (Akana et al, 1999; Gomez and Dallman, 2001; Gomez et al, 2002). Thus, the effects of intermittent morphine treatment on energy balance closely resemble effects observed in response to chronic stress, and suggest that our paradigm induces a chronic stress-like state.

\section{HPA Activity}

The effects of intermittent morphine treatment on HPA activity further characterize this treatment as a chronic stressor. Similar to our previous observation, morphine treatment resulted in adrenal hypertrophy, whereas withdrawal from morphine was necessary for thymus involution (Houshyar et al, 2001a). At $12 \mathrm{~h}$ after the final morphine injection, despite normal basal hormone values, the ACTH and corticosterone responses to the novel stimulus of tail nick \pm restraint were markedly facilitated in morphinetreated rats. Since this is a time at which rats would normally receive their next morphine injection, the resulting absence of the anticipated subjective response to morphine itself likely presented a novel stressor and may have contributed to the facilitated pituitary-adrenal responses to tail nick \pm restraint. Nonetheless, adrenal hypertrophy, thymus involution, and facilitated ACTH responses to acute, novel stimuli are hallmarks of rats exposed to chronic stressors (Blanchard et al, 1998; Dallman et al, 1992; Marti et al, 1994; Scribner et al, 1993) and provide further evidence that intermittent morphine treatment induces a 'stress-like' state. 
The facilitated ACTH response to restraint in morphinetreated rats was probably due to increased central drive to ACTH secretion since $12 \mathrm{~h}$ after the last injection CRF expression in PVN was increased under both basal and stress conditions despite normal basal ACTH and corticosterone concentrations. Under basal conditions, CRF mRNA was nearly doubled in the PVN of morphine-treated rats. Furthermore, the CRF response to acute restraint was significantly increased in the PVN of morphine-treated rats. This is the first documented change in a CRF response to an acute, novel stressor in opioid-dependent rats. These results are unlike those observed during morphine dependency induced by constant infusions or pellets (Lightman and Young, 1988; McNally and Akil, 2002; Milanes et al, 1997; Zhou et al, 1996). Our results are probably a consequence of the twice-daily partial withdrawal that accompanies our injection regimen. Chronic exposure to stress also increases CRF mRNA expression in the PVN (Imaki et al, 1991) and results in enhanced CRH mRNA responses to an acute, novel stressor (Ma and Aguilera, 1999; Ma et al, 1999). Thus, these results further support our hypothesis that intermittent morphine treatment causing dependence is a chronic stressor.

Intermittent morphine treatment also produced marked changes in extrahypothalamic CRF expression $12 \mathrm{~h}$ after the last dose of morphine. CRF mRNA in Barrington's nucleus under 'basal' conditions was significantly increased in morphine-treated rats. There is strong evidence that Barrington's neurons innervate autonomic premotor neurons (Cano et al, 2000), and that CRF-expressing neurons are involved, particularly in the sacral region of the cord (Valentino et al, 2000). Furthermore, increased urinary and fecal excretion are well-known responses to opioid withdrawal (Pinelli et al, 1998). The elevated CRF mRNA expression in Barrington's nucleus at the end of morphine treatment suggests a role for CRF in these responses to opioid withdrawal, which primarily occurs $36 \mathrm{~h}$ after the last injection. Our results are consistent with the known effects of chronic stress on CRF expression in Barrington's nucleus (Imaki et al, 1991; Krukoff et al, 1999) and provide further support for the fact that intermittent morphine treatment induces activity in the central stress network.

Intermittent treatment with escalating doses of morphine produced a marked decrease in CRF mRNA in the BNST, but did not affect CRF expression in the CeA. This is in complete contrast to the results observed in rats implanted with morphine pellets (McNally and Akil, 2002). It has been suggested that CRF in the BNST coordinates responding to tonic and/or unpredictable stressors, whereas the CRF in the $\mathrm{CeA}$ coordinates responding to phasic and/or predictable stressors (Davis and Whalen, 2001; Gray, 1993; Koob, 1999; Schulkin et al, 1998; Walker and Davis, 1997). Thus, in response to twice-daily injections of morphine that result in repeated partial withdrawal between injections a CRF response in the $\mathrm{CeA}$ would be expected, whereas in response to implanted morphine pellets that result in continuous infusion of morphine a CRF response in the BNST would be expected. However, the results obtained are opposite of those expected based on the proposed role of the BNST and $\mathrm{CeA}$ in stress responses. This suggests that the predictability and the duration of the stressor may not be sufficient conditions to predict changes in CeA and BNST CRF in stress responses. Furthermore, these results show that implanting morphine pellets and administrating repeated injections of escalating doses of morphine result in markedly different effects on the HPA system. Repeated partial withdrawal associated with intermittent morphine treatment appears to be required for induction of a chronic 'stress-like' state.

The decrease in CRF mRNA in the BNST in response to restraint in vehicle-treated rats is different from the increase observed in response to acute stressors in naïve rats (Makino et al, 1999) and rats undergoing 1- and 6-day heroin withdrawal (Shalev et al, 2001). The differences in the types of stressors, the opioid dependence paradigms, and interval between exposure to stress/ withdrawal and tissue collection probably contributed to these discrepancies. Furthermore, acute stress produces only transient increases in CRF mRNA expression in the CeA (Helmreich et al, 1999; Hsu et al, 1998) so that evaluating CRF expression $4 \mathrm{~h}$ after stress may have prevented us from observing earlier changes that may have occurred in CRF activity in this region in response to acute restraint.

The expression of AVP mRNA in the PVN was unaffected by either exposure to acute restraint or intermittent morphine treatment or the combination of the two stressors. Although changes in AVP mRNA in response to acute stress are less marked, AVP may be a predominant regulator of the HPA axis in response to chronic stress $\mathrm{Ma}$ and Aguilera, 1999; Ma et al, 1999; Makino et al, 1995). Thus, it is surprising that intermittent morphine treatment, a chronic stressor, did not alter AVP mRNA expression in the PVN. In rats receiving constant morphine infusions, AVP mRNA in the PVN is unchanged $18 \mathrm{~h}$ after spontaneous morphine withdrawal, but is significantly increased at $26 \mathrm{~h}$ (Lightman and Young, 1988). We might have seen changes in AVP expression in rats undergoing chronic (8 days) morphine withdrawal. As we did not observe any significant changes in the pituitary-adrenal responses to restraint in chronically withdrawn rats, we chose to not examine either CRH or AVP expression in those animals. Our current studies will determine if either 8 days of intermittent morphine treatment or 8 days of withdrawal causes changes in AVP expression in the PVN.

\section{Summary and Significance}

The results of this study demonstrated that opioid dependence induced by intermittent morphine treatment reduced energy balance and metabolic hormones. They also showed that hypothalamic CRF, ACTH, and corticosterone responses to an acute, novel stressor are facilitated $12 \mathrm{~h}$ after the final morphine injection when rats are undergoing partial opioid withdrawal. Intermittent morphine treatment also modified CRF activity in several brain sites, such as the BNST, Barrington's nucleus, and PVN, which are involved in the network that regulates autonomic, behavioral and neuroendocrine responses to stress. At 8 days after morphine withdrawal, at a time when all indicators of energy balance had recovered, rats displayed normalized pituitary-adrenal stress responses. These data show that chronic opioid dependence induced by intermittent morphine treatment is a chronic stressor. 
The results observed in the current study with intermittent morphine treatment are in contrast to the effects previously reported with morphine dependence induced by constant morphine exposure in rats. It is likely that cycles of marked stimulation of the HPA axis in response to repeated cycles of partial withdrawal associated with intermittent drug administration are required for the induction of a chronic 'stress-like' state. In support of this, a recent review discussed the marked differences between the 'on-off effects of the short-acting opiate heroin and the 'steadystate' effects of the long-acting opiate methadone in humans (Kreek et al, 2002). Heroin addicts are stress hyperresponsive (Cami et al, 1992), whereas methadone-maintained patients are stress hyporesponsive (Gerra et al, 2001; Mutti et al, 1992; Vescovi et al, 1989). Thus, the intermittent mode of drug administration used in the current study is probably a more appropriate model for studying physiological changes associated with opiate dependence and withdrawal in human addicts. Furthermore, it seems possible that the increased HPA responsiveness to novel stress in dependent rats as well as humans may be involved in stress-induced relapse to drug seeking.

Finally, there is recent evidence that metabolic function modulates HPA activity under basal and stress conditions (Dallman et al, 2002; Laugero, 2001). This is consistent with our observations that HPA activity was markedly perturbed while rats were in negative energy balance and that recovery of normal energy balance was paralleled with recovery of normal HPA activity. The reduced energy balance in morphine-treated rats would be expected to reduce the magnitude of the inhibitory metabolic signal to brain and thus augment brain activities induced by chronic stress. In the future, it would be interesting to examine the interactions between metabolic function and HPA activity in morphine-treated rats.

\section{REFERENCES}

Ahtee L, Atilla MJ, Calson KR, Haikala (1989). Changes in brain monoamine metabolism during withdrawal from oral self-administration of morphine and in response to a morphine challenge in the withdrawn state. J Pharmacol Exp Ther 249: 303-310.

Akana SF, Cascio CS, Shinsako J, Dallman MF (1985). Corticosterone: narrow range required for normal body and thymus weight and ACTH. Am J Physiol 249: R527-R532.

Akana SF, Strack AM, Hanson ES, Horsley CJ, Milligan ED, Bhatnagar $S$ et al (1999). Interactions among chronic cold, corticosterone and puberty on energy intake and deposition. Stress 3: 131-146.

Bartness TJ (1998). Innervation of mammalian white adipose tissue: implications for the regulation of total body fat. Am J Physiol 275: R1399-R1411.

Blanchard RJ, Nikulina JN, Sakai RR, McKittrick C, McEwen B, Blanchard DC (1998). Behavioral and endocrine change following chronic predatory stress. Physiol Behav 63: 561-569.

Boghossian S, Jourdan D, Dacher M, Alliot J (2001). Effect of morphine on caloric intake and macronutrient selection in male and female Lou/c/jall rats during aging. Mech Ageing Dev 122: 1825-1839.

Brown MR, Fisher LA, Rivier J, Spiess J, Rivier C, Vale W (1981). Corticotropin-releasing factor: effects on the sympathetic nervous system and oxygen consumption. Life Sci 30: 207-210.
Buckingham JC (1982). Effects of adrenocortical and gonadal steroids on the secretion in vitro of corticotrophin and its hypothalamic releasing factor. J Endocrinol 93: 123-132.

Buwalda B, de Boer SF, Van Kalkeren AA, Koolhaas JM (1997). Physiological and behavioral effects of chronic intracerebroventricular infusion of corticotropin-releasing factor in the rat. Psychoneuroendocrinology 22: 297-309.

Cami J, Gilabert CM, San L, de la Torre R (1992). Hypercortisolism after opioid discontinuation in rapid detoxification of heroin addicts. Br J Addict 87: 1145-1151.

Cano G, Card JP, Rinaman L, Sved A (2000). Connections of Barrington's nucleus to the sympathetic nervous system in rats. J Autonomic Nervous System 79: 117-128.

Chang SL, Patel NA, Romero AA, Thompson J, Zadina JE (1996). FOS expression induced by interleukin-1 or acute morphine treatment in the rat hypothalamus is attenuated by chronic exposure to morphine. Brain Res 736: 227-236.

Dallman MF (2001). Stress, and sickness decrease food intake and body weight: how does this happen?. In: Broome DR (ed). Dahlem Workshop: Coping with Challenge: Welfare in Animals Including Humans. Free University of Berlin: Berlin. pp 301-316.

Dallman MF, Akana SF, Scribner KA, Bradbury MJ, Walker C-D, Strack AM et al (1992). Stress, feedback and facilitation in the hypothalamo-pituitary-adrenal axis. J Neuroendocrinol 4: 517-526.

Dallman MF, Bhatnagar S (2001). Chronic Stress and Energy Balance: Role of the Hypothalamo-Pituitary-Adrenal Axis. Oxford University Press: New York.

Dallman MF, Viau V, Bhatnagar S, Gomez F, Laugero K, Bell ME (2002). Corticotropin-releasing factor (CRF), corticosteroids, stress and sugar: energy balance the brain and behavior. In: Pfaff DW (ed). Hormones, Brain and Behavior. Academic Press: San Diego. Vol 1, pp 571-632.

Davis M, Whalen PJ (2001). The amygdala: vigilance and emotion. Mol Psychiatry 6: 13-34.

Eisenberg RM (1985). Effects of chronic treatment with diazepam, phenobarbital, or amphetamine on naloxone-precipitated morphine withdrawal. Drug Alcohol Depend 15: 375-381.

Fisher LA, Rivier J, Rivier C, Spiess J, Vale W, Brown MR (1982). Corticotropin-releasing factor: effects on the autonomic nervous system and visceral systems. Endocrinology 110: 2222-2224.

Fuertes G, Milanes MV, Rodrigues-Gago M, Marin MT, Laorden ML (2000). Changes in hypothalamic paraventricular nucleus catecholaminergic activity after acute and chronic morphine administration. Eur J Pharmacol 388: 49-56.

Gerra G, Zaimovic A, Raggi MA, Giusti F, Delsignore R, Bertacca S et al (2001). Aggressive responding of male heroin addicts under methadone treatment: psychometric and neuroendocrine correlates. Drug Alcohol Depend 65: 85-95.

Gomez F, Dallman MF (2001). Manipulation of androgens causes different energetic responses to cold in 60- and 40-day-old rats. Am J Physiol 280: R262-R273.

Gomez F, Houshyar H, Dallman MF (2002). Marked regulatory shifts in gonadal, adrenal and metabolic system responses to repeated restraint stress occur within a 3 -week period in pubertal male rats. Endocrinology 143: 2852-2862.

Gray TS (1993). Amygdaloid CRF pathways. Role in autonomic, neuroendocrine, and behavioral responses to stress. Ann NY Acad Sci 697: 53-60.

Helmreich DL, Watkins LR, Deak T, Maier SF, Akil H, Watson SJ (1999). The effect of stressor controllability on stressinduced neuropeptide mRNA expression within the paraventricular nucleus of the hypothalamus. J Neuroendocrinol 11: 121128.

House SD, Mao X, Wu G-d, Espinelli D, Li WX, Chang SL (2001). Chronic morphine potentiates the inflammatory response by disrupting interleukin-1B modulation of the hypothalamopituitary-adrenal axis. J Neuroimmunol 118: 277-285. 
Houshyar H, Cooper ZD, Woods JH (2001a). Paradoxical effects of chronic morphine treatment on the temperature and pituitaryadrenal responses to acute restraint stress: a chronic stress paradigm. J Neuroendocrinol 13: 862-874.

Houshyar H, Galigniana MD, Pratt WB, Woods JH (2001b). Differential responsivity of the HPA axis to glucocorticoid negative feedback and corticotropin-releasing hormone in rats undergoing acute and chronic morphine withdrawal: possible mechanisms involved in facilitated and attenuated stress responses. J Neuroendocrinol 13: 875-886.

Hsu DT, Chen F-L, Takahashi LK, Kalin NH (1998). Rapid stressinduced elevations in corticotropin-releasing hormone mRNA in rat central amygdala nucleus and hypothalamic paraventricular nucleus: an in situ hybridization analysis. Brain Res 788: 305-310.

Imaki T, Nahan JL, Rivier C, Sawchenko PE, Vale WW (1991). Differential regulation of corticotropin-releasing factor mRNA in rat brain regions by glucocorticoids and stress. J Neurosci 11: 585-599.

Jacobson L, Akana SF, Cascio CS, Scribner K, Shinsako J, Dallman MF (1989). The adrenocortical system responds slowly to the removal of corticosterone in the absence of stress. Endocrinology 124: 2144-2152.

Koob GF (1999). Corticotropin-releasing factor, norepinephrine and stress. Biol Psychiatry 46: 1167-1180.

Koob GF, Heinrichs SC (1999). A role for corticotropin releasing factor and urocortin in behavioral responses to stressors. Brain Res 848: 141-152.

Koob GF, Le Moal M (2001). Drug addiction, dysregulation of reward, and allostasis. Neuropsychopharmacology 24: 97-129.

Kreek MJ, Borg L, Y Z, Schluger JH (2002). Relationships between endocrine functions and substance abuse syndromes: heroin and related short-acting opiates in addiction contrasted with methadone and other long-acting opioid agonists used in the pharmacology of addiction. In: Pfaff DW (ed). Hormones, Brain and Behavior. Elsevier Science (USA): San Diego. Vol 5, pp 781-830.

Kreek MJ, Koob GF (1998). Drug dependence: stress and dysregulation of brain reward pathways. Drug Alcohol Depend 51: 23-47.

Krukoff TL, MacTavish D, Jhamandas JH (1999). Hypertensive rats exhibit heightened expression of corticotropin-releasing factor in activated central neurons in response to restraint stress. $\mathrm{Mol}$ Brain Res 65: 70-79.

Langerman L, Piscoun B, Bansinath M, Shemesh Y, Turndorf H, Grant GJ (2001). Quantifiable dose-dependent withdrawal after morphine discontinuation in a rat model. Pharm Biochem Behav 68: $1-6$.

Laorden ML, Fuertes G, Gonzalez-Cuello A, Milanes MV (2000). Changes in catecholaminergic pathways innervating paraventricular nucleus and pituitary-adrenal axis responses during morphine dependence: implications of a1 and a2-adrenoceptors. J Pharmacol Exp Ther 293: 578-584.

Laugero KD (2001). A new perspective on glucocorticoid feedback: relation to stress, carbohydrate feeding and feeling better. J Neuroendocrinol 13: 827-835.

Leshem M (1988). Morphine induces delayed anorexia in rats. Psychopharmacology 94: 254-258.

Leshner AL, Koob GF (1999). Drugs of abuse and the brain. Proc Assoc Am Physicians 111: 99-108.

Levine AS, Grace M, Billington CJ, Gosnell BA, Krahn DD, Brown $\mathrm{DM}$ et al (1988). Effect of morphine and nalmefene on energy balance in diabetic and non-diabetic rats. Pharm Biochem Behav 29: 495-500.

Lightman SL, Young III WS (1988). Corticotrophin-releasing factor, vasopressin and pro-opiomelanocortin mRNA responses to stress and opiates in the rat. J Physiol 403: 511-523.
Ma XM, Aguilera G (1999). Transcriptional responses of the vasopressin and corticotropin-releasing hormone genes to acute and repeated intraperitoneal hypertonic saline injection in rats. Mol Brain Res 68: 129-140.

Ma XM, Lightman SL, Aguilera G (1999). Vasopressin and corticotropin-releasing hormone gene responses to novel restraint in rats adapted to repeated restraint. Endocrinology 140: $3623-3632$

Makino S, Schulkin J, Smith MA, Pacak K, Palkovits M, Gold PW (1995). Regulation of corticotropin-releasing hormone receptor messenger ribonucleic acid in the rat brain and pituitary by glucocorticoids and stress. Endocrinology 136: 4517-4525.

Makino S, Shibasaki T, Yamauchi N, Nishioka T, Miamoto T, Wakabayashi I, Gold PW et al (1999). Psychological stress increased corticotropin-releasing hormone mRNA and content in the central nucleus of amygdala but not in the hypothalamic paraventricular nuclei of the rat. Brain Res 850: 136-143.

Marti O, Marti J, Armario A (1994). Effects of chronic stress on food intake in rats: influence of stressor intensity and duration of daily exposure. Physiol Behav 55: 747-755.

McNally GP, Akil H (2002). Role of corticotropin-releasing hormone in the amygdala and bed nucleus of the stria terminalis in the behavioral, pain modulatory, and endocrine consequences of opiate withdrawal. Neuroscience 12: 605-617.

Milanes MV, Laorden ML, Chapleur-Chateau M (1997). Differential regulation of corticotropin-releasing factor and vasopressin in discrete brain regions after morphine administration: correlations with hypothalamic noradrenergic activity and pituitary-adrenal response. Naunyn-Schmiedeberg's Arch Pharmacol 356: 603-610.

Milanes MV, Laorden ML, Chapleur-Chateau M, Burlet A (1998). Alterations in corticotropin-releasing factor and vasopressin content in rat brain during morphine withdrawal: correlation with hypothalamic noradrenergic activity and pituitary-adrenal response. J Pharmacol Exp Ther 285: 700-706.

Milanes MV, Puig MM, Vargas ML (1993). Simultaneous changes in hypothalamic catecholamine levels and plasma corticosterone concentration in the rat after acute morphine and during tolerance. Neuropeptides 24: 279-284.

Mutti A, Folli D, Van der Venne MT, Berlin A, Gerra G, Caccavari $\mathrm{R}$ et al (1992). Long-lasting impairment of neuroendocrine response to psychological stress in heroin addicts. Neurotoxicology 13: 255-260.

Pechnick RN (1993). Effect of opioids on the hypothalamopituitary-adrenal axis. Annu Rev Pharmacol Toxicol 32: 353-382.

Pinelli A, Trivulzio S, Spezia R (1998). Effects of tizanidine administration in precipitated opioid withdrawal signs in rats. Drug Alcohol Depend 50: 81-88.

Rayner DV, Trayhurn P (2001). Regulation of leptin production: sympathetic nervous system interactions. J Mol Med 79: 8-20.

Sarnyai B, Shaham Y, Heinrichs SC (2001). The role of corticotropin-releasing factor in drug addiction. Pharm Rev 53: 209-243.

Schulkin J, Gold PW, McEwen BS (1998). Induction of corticotropin-releasing hormone gene expression by glucocorticoids: implication for understanding the states of fear and anxiety and allostatic load. Psychoneuroendocrinology 23: 219-243.

Scribner KA, Akana SF, Walker C-D, Dallman MF (1993). Streptozotocin-diabetic rats exhibit facilitated adrenocorticotropin responses to acute stress, but normal sensitivity to feedback by corticosteroids. Endocrinology 133: 2667-2674.

Shaham Y, Funk D, Erb S, Brown TJ, Walker C-D, Stewart J (1997). Corticotropin-releasing factor, but not corticosterone, is involved in stress-induced relapse to heroin seeking in rats. $J$ Neurosci 17: 2605-2614.

Shaham YSE, Leung S, Buczek Y, Stewart J (1998). CP-154,526, a selective non-peptide antagonist of the corticotropin-releasing factor 1 receptor attenuates stress-induced relapse to drug 
seeking in cocaine- and heroin-treated rats. Psychopharmacology 137: $184-190$.

Shalev U, Morales M, Hope B, Yap J, Shaham Y (2001). Timedependent changes in extinction behavior and stress-induced reinstatement of drug seeking following withdrawal from heroin in rats. Psychopharmacology 156: 98-107.

Shibasaki T, Yamauchi N, Kato Y, Masuda A, Imaki T, Hotta M et al (1988). Involvement of corticotropin-releasing factor in restraint stress-induced anorexia and reversion of the anorexia by somatostatin in the rat. Life Sci 43: 1103-1110.

Smagin GN, Howell LA, Redmann Jr S, Ryan DH, Harris RBH (1999). Prevention of stress-induced weight loss by third ventricular CRF receptor antagonist. Am J Physiol 268: R1461-R1469.

Valentino RJ, Kosboth M, Colflesh M, Miselis RR (2000). Transneuronal labeling from the rat distal colon: anatomic evidence for regulation of distal colon function by a pontine corticotropin-releasing factor system. J Comp Neurol 417: 399-414.
Vescovi PP, Pedrazzoni M, Gerra G, Pioli G, Maninetti L, Michelini $\mathrm{M}$ et al (1989). Impaired ACTH and B-endorphin response to sauna-induced hyperthermia in heroin addicts. Acta Endocrinol 121: 484-488.

Viau V, Soriano L, Dallman MF (2001). Androgens alter corticotropin-releasing hormone and vasopressin mRNA within forebrain sites known to regulate activity in the hypothalamicpituitary-adrenal axis. J Neuroendocrinol 13: 442-452.

Walker DL, Davis M (1997). Double dissociation between involvement of the bed nucleus of the strial terminalis and the central nucleus of the amygdala in startle increases produced by conditioned versus unconditioned fear. J Neurosci 17: 9375-9383.

Zhou Y, Spangler R, Maggos CE, LaForge KS, Ho A, Kreek MJ (1996). Steady-state methadone in rats does not change mRNA levels of corticotropin-releasing factor, its pituitary receptor or proopiomelanocortin. Eur J Pharmacol 315: 31-35. 